This item was submitted to Loughborough's Research Repository by the author.

Items in Figshare are protected by copyright, with all rights reserved, unless otherwise indicated.

\title{
Assessing EU aid to the 'southern partners' of the European neighbourhood policy: Who benefits from the reforms in the agricultural and industrial sector?
}

\section{PLEASE CITE THE PUBLISHED VERSION}

https://doi.org/10.1080/17502977.2015.1020736

\section{PUBLISHER}

(C) Taylor and Francis

\section{VERSION}

AM (Accepted Manuscript)

\section{PUBLISHER STATEMENT}

This work is made available according to the conditions of the Creative Commons Attribution-NonCommercialNoDerivatives 4.0 International (CC BY-NC-ND 4.0) licence. Full details of this licence are available at: https://creativecommons.org/licenses/by-nc-nd/4.0/

\section{LICENCE}

CC BY-NC-ND 4.0

\section{REPOSITORY RECORD}

Kourtelis, Christos. 2015. "Assessing EU Aid to the 'southern Partners' of the European Neighbourhood Policy: Who Benefits from the Reforms in the Agricultural and Industrial Sector?". Loughborough University. https://hdl.handle.net/2134/32986. 


\section{Assessing EU aid towards the 'southern partners' of the ENP: Who benefits from the reforms in the agricultural and industrial sector?}

\section{Christos Kourtelis ${ }^{1}$}

This article critically assesses the claims of the European Neighbourhood Policy (ENP) to support the economic development of 'southern rim' states. By amending Putnam's two-level game analysis the paper exposes the interactions between domestic, national and supranational actors and demonstrates the outcomes of the ENP reforms in the agricultural and industrial sectors. Particular attention is given to the contribution of the ENP to the development of a dual agricultural market in these countries and to the effects of standardisation for North African businesses. The article concludes by arguing that in both case studies, and despite the changes brought by the 'Arab spring', (recalibrated) elites still retain established vertical ties with domestic businesses (especially small and medium-sized enterprises) - a situation that benefits certain EU industrial and agricultural companies as well.

Keywords: European Neighbourhood Policy; Arab Spring; European Union; North Africa; agricultural reforms; standardisation; Putnam; two-level game analysis

\section{Introduction}

The Eastern Enlargement of the European Union (EU) brought new challenges to European policymakers, as the EU shared borders with new unstable states in the east and authoritarian governments in the south. To address the challenging environment that emerged from the big bang of 2004, the EU developed a new policy, with the aim to create a ring of allies with its neighbouring countries. Based on the idea of close co-operation between parties and not on a donor - recipient model of help, the European Neighbourhood Policy claims to offer bilateral incentives to develop closer and more equitable links with the region (European Commission 2009a).

Through the ENP, the EU was willing to offer more funds for more reforms to those partners who liberalise their markets and open them to European and international investors. The Action Plans (APs), which have been signed by the ENP partners and the EU, are the crux of the new policy towards the neighbouring countries. They are non-legally binding agreements, which complement the Association Agreements (AAs) that have governed Euro-Mediterranean relations for the last two decades. For the southern partners, the aim of the APs is to correct the weaknesses of the AAs, as there is a wide consensus among policymakers, and in the relevant literature, that the negative integration that the AAs pursued hindered the economic relations of the two regions (De Wulf \& Maliszewska 2010). The focus

\footnotetext{
${ }^{1}$ Christos Kourtelis is a teaching fellow of European Studies at the Department of European and International Studies at King's College London. Email: christos.kourtelis@kcl.ac.uk
} 
of the EU and the North African countries on the removal of trade barriers and border controls did not give the latter states enough incentives to alter behind-the-border controls and regulations that were deemed necessary for foreign direct investments (FDIs). In addition, emphasis on quotas mobilised groups that were threatened by the openness of the markets, especially agricultural groups that produced similar products as their North African counterparts. On the other hand, the Arab partners complained of the increasing trade deficits of their economies vis-à-vis the EU. Under these circumstances, the winners and the losers from the negative integration of the Southern partners were divided along regional lines. The European farmers covered by protectionist measures were perceived as the winners of the negotiations between the EU and the North African states. On the other hand, exporters from both regions were considered the losers of the AAs.

Yet, the regulatory changes that the ENP introduced to the North African countries have changed the distribution of costs and benefits. The deeper integration of the South Mediterranean economies into the EU market and the expansion of the regional market have resulted in new coalitions between powerful interest groups in the EU and North Africa respectively. Through this prism, the winners and the losers cannot be distinguished into discrete European and North African categories. Therefore, a new framework is needed to explain the evolving Euro-Mediterranean relations.

This article will analyse the agricultural and industrial reforms that the ENP has suggested to the Tunisian and Moroccan governments, in order to identify the 'winners' and the 'losers' of the new policies. The two countries signed APs in 2004 and they are more deeply integrated into the EU market than the other regional partners. According to the European Commission (EC), reforms in these sectors are of paramount importance for the two North African economies for obvious reasons. The agricultural sector absorbs a high percentage of their workforce and the industrial sector has significant input in the GDP of the local economies. For example, employment in the Moroccan agricultural sector exceeds $40 \%$ of the total workforce, while in both countries the industrial sector is regarded as the engine of the national economies. Close to the perceptions of other international organisations that operate in the region (e.g International Monetary Fund, World Bank) marketoriented reforms will increase the competiveness of these countries and help them to expand trade and job creation (López-Cálix, Walkenhorst, \& Diop 2010).

The article analyses the outcome of the ENP reforms in the two sectors before and after the Arab Spring. For the EU institutions, the Arab uprisings were a turning point for the policies of the Union towards the countries of North Africa. The strategy paper of the EC after the beginning of the revolts linked 'the unrest in several Southern Mediterranean countries [...] to economic weaknesses' (European Commission 2011c, p. 7) and underlined the need for policies that promote inclusive growth. Central to this approach was the role that Small and Medium Enterprises (SMEs) could play in the 'inclusive economic development' of the region and their 'critical role in job creation' (European Commission 2011c, p. 7). 
This study analyses these claims and it argues that due to the unchanged configuration of power within the EU and the North African states, the orientation of the North African governments in regards to agricultural and industrial policies have not changed after the Arab Spring. Under these circumstances, the related reforms, and the EU aid programs that support them, continue to contribute to the development of a dual agricultural market in Morocco and Tunisia and to the marginalisation of the local SMEs for the benefit of the local elites and the European exporters.

To assess the reforms and their consequences in the two ENP partners, this article uses Putnam's two-level game analysis. This framework allows us to identify the win-sets in both regions and the interaction between the domestic, the national and the supranational levels. To do this the article will first demonstrate the existing critiques of the ENP and show why a two-level game framework can better explain the performance of the policies. Next, it will analyse the impact of the reforms on the domestic level, both in the EU and the two North African partners. The final section evaluates the post-Arab Spring EU programs in North Africa.

\section{Critiques of the ENP and the merits of a two-level game analysis}

Critical approaches to the ENP argue that the policy is another attempt of the EU to dominate the southern shores of the Mediterranean Sea (Holden 2009; Joffé 2007; Kourtelis 2011; Talani 2009). According to these studies, since the creation of the EU's first comprehensive strategy in 1995 (the Euro-Mediterranean Partnership EMP- or Barcelona Process), EU policymakers have intensified their attempts to persuade North African statesmen that the benefits of closer cooperation with the EU outweigh the costs of domestic adjustments in neighbouring countries. In addition, the provision of financial assistance is used as a sweetener and reward to governments, which fulfil their political commitments and implement the reforms signed in the AAs and APs (Attinà 2003; Wesley Scott 2005).

Through this prism, the ENP continues the work of the EMP and further integrates the Arab partners in the common market for the advantage of the EU (Hettne 2007; Holden 2009; Joffé 2007). At the economic level, the growing North African markets, the abundance of energy resources and cheap labour offer new opportunities to the European companies and the main objective of the ENP is to make the North African economies satellites of the EU (Holden 2009).

At the political level the main objective of the EU is to maximise its security (Barbé \& Johansson-Nogués 2008; Johansson-Nogués 2004; Talani 2009; Zaiotti 2007). Drawing examples from the increasing securitisation of immigration and the Schengenisation of the EU's foreign policies (Bensaad 2007), many authors argue that the ENP has been used to further externalise the EU's security policy, making North Africa an advanced check point for the control of illegal migration (Bilgin 2009; Daguzan 2005; Holm 2008; Lutterbeck 2006).

Focusing on this exploitation helps the analysts of the ENP to explain the relationship between material and ideological aspects of power, the function of 
capitalism at the regional level and the priorities of the EU. Yet, critical analyses often fail to clarify the specific interests that stand to benefit from this relationship. Criticisms of the neoliberal concepts of privatisation, deregulation and liberalisation of the market mention the fact that the establishment of a free market area creates new opportunities for Europe, but without specifying whether the beneficiaries of the EMP and the ENP are the dominant European classes, the big European member states or specific sectors of the European and North African economies. On the other hand, articles that focus on the modes of governance through which the EU organises its external relations explain the differences between the components of the institutional arrangements which have been created in the last ten years to govern the Euro-Mediterranean relations (Johansson-Nogués 2011), the importance of the actors involved in the formation of the Euro-Mediterranean strategies (Gillespie 2011a and 2011b; Heijl 2007), the failures of previous governance modes in specific sectors (such as energy) that inform later frameworks (Darbouche 2011) and the shift from regionalism to bilateralism (Bicchi 2011).

This gap leaves unanswered the role of the dominant social forces within the ENP. Therefore, a more precise definition of the different interests that are involved in the ENP and how they influence the economic development of the partners is needed. At this point, Putnam's two-level game framework is of great help, as it follows a sectoral approach and at the same time assesses the interaction between actors at different levels of the ENP. This method makes clear which interest groups win and which lose from the policy. In addition to producing a more nuanced analysis of the winners and losers of agricultural and industrial reforms, a two-level game analysis provides a more detailed picture of the nature of the domestic win-sets. Furthermore, it helps to realise the role that the politicisation of the APs played in the ratification of the ENP in the EU, in Tunisia and Morocco, the bargaining tactics of statesmen and the reverberation of international pressures within domestic politics.

Putnam's initial assumption is that both domestic and international politics matter in the conclusion of an international agreement and that negotiations occur simultaneously at both levels. At the domestic level, the ratification of international agreements is not only a parliamentary matter. It asks wider consensus and its successful implementation involves different social actors, such as interest groups, state agencies and public opinion (Putnam 1988).

Crucial to our understanding of the domestic dynamics is the definition of the win-set of every side. The win-set is the majority coalition and offers the platform for policymakers to conclude international agreements (Putnam 1988). Ideally, policymakers would like to represent the widest possible coalitions as their preferences are very likely to overlap with the interests of the other country's win-set. Conversely, small win-sets hinder the efforts of state representatives to reach an agreement, as politicians find it hard to ratify or implement international agreements in their countries. This situation often leads to the involuntary defection of statesmen from international negotiations. However, there are cases when small win-sets offer a convenient excuse for negotiators for the partial implementation of international policies. Yet, even in this case, negotiators claim that domestic support for reforms is 
weak and they are unable to proceed to necessary reforms. Voluntary defection is baptised as involuntary for reputational reasons, especially when the two sides have established relations (Putnam 1988).

Another characteristic of Putnam's work is that he determines the size of the win-set on a single axis. On one end, we can find the isolationist groups, which oppose international cooperation (and trade liberalisation) and on the other are gathered all the supporters of increased trade openness (Putnam 1988). In situations where the costs and benefits are shouldered by fewer actors, the mobilisation of the domestic groups is more intensive. At this point, the skills of politicians are demonstrated by their ability to trade-off across different issues in order to achieve an agreement. This counter mobilisation of interest groups and the synergistic linkage of different issues can be found in the literature of the political economy of Euro-Mediterranean relations, especially when analysts compare the preferences of European agricultural lobbies with those of the European exporters (Montanari 2007).

Yet, this is not the only factor that determines the power of the domestic interest groups and more elaboration is needed in order to understand which parameters shape the societal demands for protection or for increased international cooperation. Besides the societal counter mobilisation argument, sectoral attrition provides useful insights for the erosion of the size of protectionist groups. According to this explanation, the impact of the increased international competition determines the power of societal actors (Hanson 1998). In other words, uncompetitive sectors lose their political and economic significance and their size diminishes to the extent that they are not strong enough to resist any reforms. In addition, the increasing dependence of one sector to the global political economy can drive subgroups to different preferences and to a change of their protectionist orientation, which weakens the overall power of the group (Hanson 1998). As shown below, the expansion of many South European agricultural firms in the North African markets helps to explain the internal dynamics of the agricultural sector (especially in the EU) and changes in the size of domestic coalitions.

\section{The ENP agricultural reforms: Marginalisation of small farmers in the EU and reinforcement of a dual agricultural market in North Africa}

Since the 1980s an increasing number of studies argues that state dominance in the agricultural sector has been a barrier to growth, as political elites manipulate the food sector for political and economic gains (Bates 1981; Borras 2003; Loxley 1983). The solution that is promoted is the openness of the market to new actors that can decrease the dominant position of counterproductive states.

However, this article argues that the openness of the food sector did not change the dominant position of the North African state in agriculture, as many policymakers in the EU envisioned. Actually, the ENP APs reproduced the power of the state elites and contributed to the creation of a dual agricultural market. This market benefited the North African farmers that export their crops and marginalised 
further the substitute farmers that sell their products domestically. How did this happen?

The ENP APs required similar reforms in both Tunisia and Morocco. Regarding agriculture, the aim is to 'facilitate trade in agricultural products with the EU' (European Commission 2004a and 2004b). The focus of the APs is on nontariff barriers (NTBs), such as the modernisation of the agricultural sector and improvements for consumer health and safety in both countries. Regarding the promotion of agricultural trade, while refraining from sensitive issues (such as quotas and tariffs) that tend to mobilise farming lobbies, the ENP reforms gave more room for manoeuvre to political leaders of both regions. This situation has affected the formation of win-sets in the EU and in North Africa. The low politicisation of international agreements favours their conclusion (Putnam 1988) and in the case of the ENP the low politicisation of the agricultural reforms allowed the quick ratification of the APs in the EU countries (Buras \& Pomorska 2006).

Due to the low political status of the ENP, protectionist groups within the EU were not provided the fertile ground that was necessary for their mobilisation. Nevertheless, low politicisation was not the only factor that facilitated the policy's ratification. For the last three decades, the pressure of the US and developing countries for changes in the EU's protectionist agricultural policies has continually escalated. As a result, the EU tends to showcase any reforms that promote the free trade of food products, as a means of demonstrating how it has adopted a liberal approach towards agricultural trade. In addition, the price of food products were increasing in the EU faster than the average inflation rate (Eurostat 2010) and the further liberalisation of the agricultural market was seen as a means to keep the food prices low (European Commission 2006, p. 3).

However, it is wrong to assume both that North African countries have been the primary beneficiaries of these ENP reforms and that European farmers face the consequences of a more open agricultural market. In fact, the ratification (and the nature) of the ENP APs is linked to the access of EU companies and products into North African markets. This situation makes the intra-sectoral game a more complicated issue.

According to the Tunisian Foreign Investment Promotion Agency (FIPA) more than ten per cent of the nine hundred and fifty agricultural companies with more than ten people are owned entirely by foreigners or have foreign shareholders, especially French nationals (FIPA, 2006). According to the prevailing logic, these companies bring their technical know-how and marketing expertise to North African markets, whereas the local industries handle supply, field knowledge and distribution (FIPA 2006 and 2014). In Morocco, the privatisation schemes (that were implemented after the creation of the ENP) attracted French and Spanish farmers and allowed the expansion of European agricultural operations southwards, into North Africa ("A new national strategy for agriculture" 2008). The increasing internationalisation of the South European agricultural sector changed the preferences of the South European farmers, who had previously worked as a solid block against the openness of the food sector. 
The liberalisation of the North African agricultural markets allowed the expansion of a pro-liberal win-set with arms in both sides of the Mediterranean Sea, but the approach of the two North African countries towards liberalisation was not exactly the same. In Tunisia, one factor that allowed the perpetuation of a dual agricultural sector was the piecemeal approach of the government towards the liberalisation of the market. The Tunisian authorities opened the market for some products, but at the same time continued to set maximum prices on wholesale and retail markets without providing any support to the farmers. The aim of this pricing policy was to control inflation (a macroeconomic priority of the ENP) by keeping the prices low. Yet, it has affected asymmetrically the Tunisian farmers. The small producers of vegetables were largely hit by government's policy, whereas the larger producers of wheat and milk were excluded from this measure (Minot, Chemingui, Thomas, Dewina, \& Orden 2010, p. 105). At the same time, the liberal restructuring of agriculture (and the problematic access to credit for small farmers) increased the price of land, which gradually was passing to the hands of few large landowners (Jouili 2009).

Through these moves the Ben Ali regime managed to secure the interests of large landowners, but they were not alone in benefiting from the ENP reforms. Their partial implementation allowed the formation of a win-set, which embraced other established businesses of the sector. For example, the selective use of NTBs insulated companies that belonged to Ben Ali's family from competition. High NTBs in sugar, which exceeded $28 \%$ of tariffs equivalent (Chemingui \& Thabet 2007), protected the work of Tunisie Sucre, a sugar refinery that was owned by Belhassen Trabelsi of Ben Ali's family (Rijkers, Nucifora, \& Freund 2014). ${ }^{2}$

State agencies that were controlled by the regime, such as the Grain Board (it controls the imports of grains), the National Edible Oils Board (responsible for the importation of vegetable oil) and the Tunisian Trade Board (responsible for coffee and tea imports) authorised very few private agents to import these products and offered the opportunity to the state to use licences for political patronage (Minot et al. 2010). In many cases and without any justification, the state refused to authorise private companies to import agricultural products and the time-consuming custom clearance process, which can take about three weeks, discouraged private companies to invest in the importation of these products. This resulted in the reproduction of state power through clientelistic politics and yielded benefits to a small group of importers, who had close ties with the state elites and benefited from oligopolistic pricing.

Morocco followed a different strategy to support its interests and exportoriented farmers. Contrary to the Tunisian example of protectionism for state-owned companies, the Moroccan authorities enacted privatisation policies that targeted state companies with a long history in the management of land that was recovered

\footnotetext{
${ }^{2}$ Out of the 220 Ben Ali's firms that were confiscated only seven operated in the food sector. The other firms mainly focused on real estate, telecommunications and other various services (Rijkers, Freund, \& Nucifora, 2014). Thus the focus on this paper is how the ENP reforms benefited primarily the large food producers at the expense of small farmers.
} 
from foreigners over the last four decades. During the first two years of the ENP SODEA (Société de DéveloppementAgricole) and SOGETA (Société de Gestion des TerresAgricoles) were restructured and their privatisation resulted to the dismissal of more than 3,000 employees ("Privatisation in Morocco extends to state land leases" 2005). In addition, the Moroccan government privatised 46,000 hectares in 2004, 56,000 hectares in 2005 and almost 39,000 hectares in 2008 ("A new national strategy for agriculture" 2008). The EU supported these initiatives as they would improve the sector's organisation and capital stock (Directorate General for Economic and Financial Affairs, 2005).

Yet, the European policymakers assumption that the reorganisation of the sector through privatisation schemes would decrease the power of the state were not accurate. What these initiatives did was to continue the deprivation of Moroccan small farmers. A first look into these reforms shows that the state managed to secure significant revenues. Actually, these reforms added $\$ 610 \mathrm{~m}$ to the 2014 state budget ("A new national strategy for agriculture" 2008). In addition, the state showed that it was determined to pursue market based strategies for the development of the country by minimising its intervention in agriculture through inefficient public enterprises. According to the Moroccan Agriculture Minister, Mohand Laenser, these privatisations were a part of

'a policy of disengagement from the agriculture production sector, which was in line with the evolution of the national and international economic environment' ("Morocco to sell farmlands to foreign bidders" 2004; "Privatisation in Morocco extends to state land leases" 2005).

However, the state continued to play an important role in other aspects of agriculture, such as the organisation of irrigation programmes. Considering North African climate conditions, these programmes are crucial for agricultural productivity and primarily benefit large-scale farmers (Minoia 2012). The involvement of the EU in water management and the support that Morocco gets from the European Investment Bank for irrigation projects (ENPI 2012; "Morocco: EIB lends $42.5 \mathrm{mln}$ for irrigation and agriculture" 2014) is not related to the failure of traditional policies to manage natural resources, but to the introduction of neoliberal principles in natural resource management. The EU promotes three key neoliberal principles in water management through the ENP. First, the technical support it offers makes obsolete (or even irrelevant) any traditional knowledge, especially for commercial crops. The equipment that farmers need is expensive and can be afforded only by big farmers. Second, the EU supports the establishment of Public-Private Partnerships (PPPs), which are supposed to reduce state control over water resources and rural areas. Yet, anthropological fieldwork in areas where ENP funds have been allocated show that the EU-funded schemes have been governed by centralised authoritarian powers and have reproduced the power of the established agrarian elites (Minoia 2012). 
Third, the EU supports the production of commercial crops, which can compete in international markets. Under this mandate, the state began to promote private initiatives as well as the further integration of agriculture into the global (or the EU) market (Moyo 2007). Stronger trade relations with the EU came to be perceived as a key development tool. However, it was only through the creation of large-scale farms that a larger stake into the EU market could be achieved. To foster its relations with the EU, the Moroccan government allowed for the first time to foreigners to participate in the privatisation programmes. The Moroccan authorities expected many Spanish and French farmers to enter the programme, due to the lower tariffs that the Moroccan products enjoy to enter the US market than the EU ones ("A new national strategy for agriculture" 2008, "Privatisation in Morocco extends to state land leases" 2005). Large-scale farms were perceived as capital-intensive investments and as more productive than small-scale holdings, the owners of which are deemed by the government as suffering from poor managerial skills. In addition, as a result of inheritance practices in Morocco, $69 \%$ of farms have been divided into an average size of less than five hectares, which, according to the government, further limited the sector's productivity. The new government scheme therefore claimed to address these problems in order to reduce the provision of subsidies to farmers, which were criticised in the ENP reports. The reduction of subsidies was followed by the exemption of agriculture from direct taxation, which benefited primarily large farms (European Commission 2008).

The aforementioned findings show that the Moroccan privatisation schemes (that were implemented since the beginning of the ENP) ${ }^{3}$ extended the domestic win-set that benefited from the reforms, as groups of South European farmers have invested in the country. Yet, as in the Tunisian case, small farmers were excluded from the relevant schemes.

An additional burden for small-scale farmers in the two North African countries is related to the Sanitary and Phyto-Sanitary controls (SPS) (Cadot, Augier, Gourdon, \& Malouche 2011). These controls are among the key actions of all the AP and are allegedly aimed at securing the safety and quality of the agricultural products. However, it is important to consider the impact, whether intended or unintended, of the SPS controls on the agricultural sector of the North African economies. According to many analysts, SPS controls have impeded agricultural trade between developing and developed countries, by imposing import bans, by discriminating supplies or by raising costs (Henson \& Loader 2001; Jaffee 1999; Petrey \& Johnson 1993; Sykes 1995). The high cost of compliance varies and depends on the size of farms and crops, but in some developing countries can exceed $\$ 200,000$ per plant (Henson \& Loader 2001) meaning that they are only affordable by a very small number of farmers. As a result, the structural inequalities between the 'global north' and 'global south' have been further entrenched.

\footnotetext{
${ }^{3}$ The privatisation of state companies and state-owned land began in the mid-1980s. Yet, the focus of this analysis is on the impact of privatisation projects after the beginning of the ENP.
} 
Yet, for the Moroccan and Tunisian authorities participation in the SPS practices was perceived not only as a key issue for the development of their agricultural trade with the EU, but also as a motor of GDP growth. This has benefited primarily the large farmers as the cost of getting a certification for exporting to the EU is expensive. For example, the EUREPGAP certificate costs about $\$ 1,200$ per farm, meaning that in certain products, such as vegetables, a farmer needs to have more than a hundred hectares of land. ${ }^{4}$ For the exportation of citrus a farmer needs more than four hundred hectares of land (Aloui \& Lahcen 2004; Cadot et al. 2011). To this cost, one should add the expenses for buildings and infrastructure to address various issues (such as environmental hazards, workers health, water and pesticides storage and management) required to meet EU standards. For example, only for the first year, a Moroccan farmer will need more than $\$ 70,000$ to implement the EUREPGAP standards on a ten hectares tomato farm (Aloui \& Lahcen, 2004 p. 26).

In addition, farmers who are not affiliated with any cooperative system cannot implement SPS controls. Given the liberalisation of the market and the disengagement of the state from agriculture, farmers have to bear the costs of quality assessments. Large-scale farmers can tolerate these costs, since they have the funds to apply the standards. They also create networks or their own packing houses to export to the EU. These packing houses are subject to different certifications, but they are well prepared to adopt the new rules and export to the EU market. (Aloui \& Lahcen 2004).

On the other hand, the state-owned packing houses, which help small scale producers, are slow in the adaptation of quality standards and their input to exports is much smaller (Aloui \& Lahcen 2004). Furthermore, the limited EU programmes that offer technical assistance (especially towards small farmers) cannot help the small producers to export their crops. The fact that SPS measures require largescale investments over extended periods of time has contributed to the creation of a bimodal agricultural market that distinguishes farmers into exporters that prefer to sell their products to the EU market for higher returns and into subsistence farmers that receive limited assistance and refuse to switch to market-driven crops in order to survive.

\section{The implementation of the ENP industrial reforms: The effects of standardisation}

Since the mid-1990s, the AAs between the EU and the North African countries have gradually removed tariffs and quota restrictions in order to enhance the trade of industrial products. However, the business communities of both regions have underlined the problems that stem from different standards as one of the most important barriers that hinder the further development of trade relations between Europe and North Africa (ERT 2005; "Euro-Mediterranean Business Summit sets up

\footnotetext{
${ }^{4}$ EUREPGAP was established in 1997 as a private initiative of retailers belonging to the Euro-Retailer Produce Working Group. It demonstrates good agricultural practices and ensures access to the EU market.
} 
business confederation" 2002). Under these pressures, the partner countries agreed to harmonise their legislation to the EU standards and conclude a conformity assessment agreement (ACAA).

According to the EU, Agreements on Conformity Assessment and Acceptance of Industrial Products (ACAAs) are 'a specific type of mutual recognition agreement based on the alignment of the legislative system and infrastructure of the country concerned with those of the European Community' (DG Enterprise and Industry 2013)

ACAAs between the North African countries and the EU would promote the partners' exports to the EU market, as their products could be placed there directly without additional checks at the borders. However, their conclusion requires other prior steps including the adoption of the EU acquis; the upgrade of the standardisation, accreditation, conformity assessment and market surveillance infrastructure; and the cooperation of the partners bodies' with the EU authorities.

Hence, an ACAA with the EU requires a change of the industrial policies of the two countries. This slow change has delayed so far the conclusion of an ACAA. Since their independence, the North African industrial policies prioritised the development of the domestic market for the local products. Through these policies North African policymakers have focused more on the differential taxes and subsidies to selective sectors of industry rather than harmonising product standards. Under this logic, modern infrastructure for testing products, developing certification methods and accreditation bodies had received little attention. That is why the focus of the APs was on the improvement of the institutional capacity of the partners for implementing the harmonising programme.

Tunisia and Morocco have made fast progress for the conclusion of an ACAA and this is a result of their dependence on EU trade. Tunisia upgraded (and made independent) the accreditation bodies and aligned related laws to the EU acquis (for example laws about consumer protection, and on import and export controls). Morocco has managed to improve its market surveillance mechanisms, but it needs to adopt EU technical standards faster, as these are crucial for the conclusion of the ACAA (DG Enterprise and Industry 2008).

An additional significant factor for the conclusion of an ACAA is the selection of the priority sectors for the harmonisation of their standards. According to the ENP reports, these are a subject of negotiations between the partners and the EU, but the final decision is left to the partners, who must choose at least three sectors to harmonise with the EU standards.

The fact that the choices of the partners are similar leads to interesting conclusions regarding the role of the trade volumes between the two countries and the EU and about the asymmetrical negotiating power between the EU and the North African countries. ${ }^{5}$ For Ghoneim, the selection of the sectors is a parameter of health

\footnotetext{
${ }^{5}$ The priority sectors for the two countries are the following: electrical appliances and building materials for Tunisia. Construction products, electrical appliances, pressure equipment, medical devices for Morocco (European Commission 2009b and 2011b).
} 
and safety, of the EU-ENP partner trade and of the development of the related industries (Ghoneim 2007). Yet, in order to understand why certain sectors are chosen over others, it is important to consider the negotiating power of the EU in the selection of the priority sectors.

According to the Tunisian authorities, the EU asked the country to select sectors of the 'New Approach' for harmonisation (Tunisian Ministry of Industry and Technology n.d.). The 'New Approach' was adopted in 2008 with the objective to 'particularly benefit small and medium sized enterprises' (DG Enterprise and Industry, 2012b). Through this prism, the pressure exerted on North African countries to conclude the ACAAs does not reflect the hegemonic or exploitative nature of the EU, but rather the benevolent European support for the growth of North African SMEs.

Yet, the main feature of this technique is that it leaves 'the definition of technical requirements to the economic actors' (DG Enterprise and Industry 2012b). This is a deviation of the older standardisation process, which was organised by the states. It is now the EU industries that set the market standards, whereas state mechanisms or independent bodies merely check to ensure that products meet these standards. This situation reinforces the privileged position of European firms, because they set the standards of the ACAA in the chosen fields. As they are the ones setting the standards, they are always a step ahead in the process of standardisation. In addition, by imposing the same costs to the other firms for complying with the standards they have set, these firms can expand their businesses into the markets of the partners and can easily tolerate the additional costs of standardisation (Sykes 1995).

Harmonisation of the partners' standards with those of the EU reinforces the bonds between North African economic actors, who find it easier to trade with the EU rather than with their Arab neighbours, and the EU. Arab exporters are more supportive of initiatives that enhance EU-Mediterranean rather than intra-Arab trade. The much lower growth of trade between the Agadir members against their bilateral trade with the EU highlights this situation. In addition, low societal pressure on Arab governments for regional integration allows states to be the sole negotiating actors in these agreements.

These conditions distort the logic that inspires the integration of developing countries, which is based on the gains that they could have from the reduction of the trade barriers that exist between them. The opportunities that 'a stake in the EU market' offers operate as a barrier to the creation of an Arab regional market, with distinct regulations that could protect the local industries from uneven competition, as it had happened in the first years of the European integration. Instead, the profitability of domestic investments is undermined from the penetration of European companies.

EU policymakers, who operate as agents of the European pressures for the further liberalisation of the North African markets argue that trade between North African producers has increased due to EU support and regional initiatives that rely on EU standards (Obeidat 2014). Yet intra-North African trade is marginal and North 
African exports rely heavily on imported inputs, especially from the EU (United Nations Economic Commission for Africa 2013). In other words, EU attempts through the promotion of technical standards and regional initiatives to make the North African economies satellites of the EU market rather than equal partners. Similar to its action in other regions, the EU uses these agreements as a means to further entrench its 'first mover advantage', in order to shape the standards of the regional market in favour of the European companies (Egan 2002).

The industrial part of the ENP APs includes more direct provisions for the SMEs by supporting the implementation of the Palermo Action Plan. This is a nonlegally binding document, which includes ten dimensions for the development of industrial trade and the support of SMEs and was approved in 2003 by the Mediterranean Trade Ministers (DG Enterprise and Industry 2012a). These dimensions entail changes to the existing regulatory and legislative frameworks of North African countries with the aim to 'create an environment conducive to investment and private sector development' (DG Enterprise and Industry 2012a).

The heavy reliance of the Tunisian and Moroccan GDPs on SMEs was the main factor for the rapid implementation by both governments of most key points of the Palermo AP. In both countries, the creation of small businesses was among government priorities. In Tunisia, two public banks were created for the provision of cheap credit to SMEs (DG Enterprise and Industry 2008).

Yet, these regulatory developments do not seem to yield significant benefits for the North African SMEs. The SME sector in the two countries is undercapitalised and suffers from low value-added weaknesses. For example, in Tunisia, which is the best performer of the Palermo AP, less than 5\% (4,75\%) of the SMEs are innovative contrary to $47,2 \%$ of the EU SMEs in the manufacturing sector (DG Enterprise and Industry, 2008). Additionally, in many cases, the SMEs feel underrepresented, as the business associations promote the interests of the big companies and the SME struggle to create synergies with the international companies that operate in the countries (DG Enterprise and Industry 2008, p. 93). Under these conditions, the implementation of the ENP AP offers asymmetrical advantages to North African enterprises. The convergence of the regulatory framework facilitates FDIs in both regions, but it offers limited opportunities to the North African SMEs to benefit from the integration of the North African countries.

\section{Business as usual? The EU's agricultural and industrial initiatives towards the North African countries after the Arab Spring}

The EU response after the Arab Spring was to announce a new and more ambitious ENP with the aim to make the policy more effective. According to Baroness Ashton, the new ENP is based on three axes: Money, Market Access and Mobility. These new characteristics of the ENP were accompanied by a new rhetoric in the EU's strategy papers. After 2010, the EU strategy papers have emphasised the need to support the local SMEs and for designing policies for inclusive economic development (European Commission 2011c). According to the EC, the first aim of 
the EU for the sustainable economic and social development of the ENP countries is to

'support partner countries' adoption of policies conducive to stronger, sustainable and more inclusive growth, to the development of micro, small and medium-sized companies and to job creation' (European Commission 2011c).

The new orientation of the EU is supposed to move away from the neoliberal logic of the past and the new programmes are supposed to mitigate the economic problems that emerged after the revolts. However, a more careful analysis of the programmes that the EU has created for supporting the North African agricultural and industrial sectors show that the impact of the Arab Spring uprisings has not affected substantially the nature of the EU reforms or the coalitions that benefit from them. In fact, the new programmes perpetuate the old dichotomies that were discussed above, as they rely on the same neoliberal recipe.

More specifically, in the aftermath of the Arab Spring, the EU promise for inclusive growth in the agricultural sector was translated into the European Neighbourhood Programme for Agriculture and Rural Development (ENPARD), which was launched in 2012. The main aim of the programme, which is modelled on older (and successful according to the EC) EU initiatives towards East Europe and the Balkans, is to modernise and expand agricultural production through tailored dialogues (European Commission 2012). The implementation of the programme is still at an embryonic stage, but based on the aforementioned analysis, some issues raise concerns about its success.

First, the implementation of the programme in East Europe and in the Balkan countries should be considered at its best a partial success. In the Balkan countries, Croatia appears as the most successful case, yet even there administrative problems and lack of support to agricultural subsectors are still apparent. In Turkey, the programme has been used to benefit mainly large exporters or for the reproduction of AKP's power in rural areas (Kourtelis 2014). The reason for the different outcomes is that the programmes relied on national strategies, which serve different priorities in the New Member States and candidate countries.

Under the same notion, ENPARD does not aim to change the existing national strategies of ENP partner countries, but to reinforce them (European Commission 2012). The logic of the EU is to show that it does not aim to behave as hegemonic power in the region and that it respects the ideal of partnership. Yet, by acting as a 'genuine partner', the EU allows the continuation of the existing national strategies, which (as shown above) have asymmetrically benefitted the interests of large farmers, meaning that ENPARD will support policies that widen the gap between export oriented farmers and small scale producers.

Second, a clear stated objective of the programme is to increase the food safety and the quality standards of the North African products. The rise of standards may benefit customers but, as shown earlier, it does not allow the small producers to participate in the wider agricultural market. What is anticipated from stricter controls is the increase of the costs of the phyto-sanitary certificates. Financing rural 
infrastructure and funds to young farmers could somehow mitigate the increasing costs of compliance with the EU rules, but it remains to be seen how much money will be devoted to these areas and how the funds are going to be allocated to the modernisation of private or state packing houses. So far, and judging from the implementation of the same programmes in the Balkans, support to rural infrastructure was questionable (Knudsen 2013). In addition, the phyto-sanitary certificates penalise the agricultural trade between south partners, as harmonisation with the expensive EU standards imposes higher costs to domestic farmers without adding any competitive advantage when exporting to third countries (Cadot et al. 2011 p. 5).

The neoliberal transformation of the agricultural sector does not leave much room for improvement. This transformation has condemned large parts of the agricultural sector and has not stopped the uneven development of a dual agricultural market. This dual market has on one end a win-set of large exporters, which has established ties with the political regimes (old and new) of the two countries and benefits from the implementation of the EU programmes and openness of the markets and on the other the subsistence farmers, who are excluded from the related projects. Under these conditions, the chances for ENPARD to become a successful programme are slim.

One can witness similar continuities with regards to industry in the aftermath of the Arab Spring. Even if the EC mentions the need to support the local SMEs for the creation of inclusive growth in the North African countries (European Commission 2010, 2011a and 2011c), the new programmes appear inadequate to meet the demands of the SMEs. For example, the new Support to Partnership, Reform and Inclusive Growth (SPRING) programme, which was created after the Arab revolts for the support of SMEs recycles old tools under a new language (Amirah-Fernández \& Behr 2013). The programme's stated aim is to continue supporting the efforts of the North African countries to create a better regulatory framework for businesses. However, it does little to provide direct support to SMEs. Only $65 \mathrm{~m}$ euros were committed in 2011 for the whole programme and about $285 \mathrm{~m}$ were committed for 2012 (European Commission 2011c).

In addition, the responses of the North African countries show that the configuration of power has not changed after the revolts and that the new regimes have merely attempted to recalibrate their relations with local business elites. In order to do so, post-'Arab spring' governments in Tunisia and in Morocco have formed new deals with companies connected to the political leadership. Similar to arrangements made under the former regimes, these 'connected companies' have been offered new special privileges and favourable access to markets, credit and government services. The strong ties that these firms continue to enjoy with the governments have allowed them to continue to outperform their competitors (Morsy \& Zouk, 2013) and despite the changes in the leadership of the Tunisian state, the economic status quo continues undisturbed to enjoy the privileges of the Ben Ali era (Nucifora, 2014). Under these conditions, the low competitiveness of unconnected SMEs has not been dealt with adequately. At this point, the words of Patricia Augier, 
deputy director of Centre De Recherche en Developpement Economique et Finance Internationale (DEFI), adequately capture the reality for the Moroccan (and Tunisian) SMEs:

Credit is generally awarded to exporters and big companies that have foreign capital or significant lobbying power; paradoxically, indebted SMEs find it difficult to get financing. Moreover, bank guarantees in Morocco are generally mortgages on personal movable or immovable property something of an obstruction to business growth! [...]SMEs may be affected by competition from the black market and significant gaps in local tax laws, giving rise to a lack of visibility. Fiscal differences and red tape mainly affect small businesses - generally those that do not export or have no foreign capital ("Moroccan SMEs plagued by opaque credit access" 2010).

In other words, the experience of agricultural and industrial reforms in the two North African countries shows clearly that the ideas of inclusive growth and fair development remain intangible. In both cases, the new programmes reproduce older dichotomies or create new arrangements, which benefit the already privileged groups of both sides of the Mediterranean Sea.

\section{Conclusion}

The agricultural and industrial reforms prescribed by the ENP to North African countries expose the role of domestic politics in the EU external policies towards the Arab Mediterranean countries. Contrary to previous studies that separated the winners and the losers of the Euro-Mediterranean agreements along regional lines, the application of Putnam's two-level game helps to set the win-sets on sectoral lines and assess more accurately the interests that benefit and lose from the EuroMediterranean agreements.

According to the findings of this work, different dynamics have shaped the power of the domestic social forces and the results of the ENP. The main element that characterised the formation of the domestic coalitions is the import or export-led orientation of the relevant actors.

The political conflicts between export-oriented companies and protectionist interests about international agreements are not new. Yet, what is important here is that so far the protectionist or export-led descriptions have been attached to entire sectors of the EU and North African economies. This way of portraying the EuroMediterranean relationship has offered a distorted picture of the businesses that supported the ENP agreements with the North African partners and concealed more complicated intra-sectoral divisions and interest group politics.

The sectoral mapping of the EU and North African economies shows that in the EU and North African states the agricultural sector was divided into subgroups that had different priorities. In Europe, these differences informed the anaemic response of the European farming lobbies against the ENP reforms. The low politicisation of the policy, pressures from international competition, the rise of 
inflation and the change of key agricultural industries have contributed to the deprivation of small farmers in the EU. At the other side of the Mediterranean Sea, the state elites have managed to find ways to manipulate the ENP reforms and retain their power in the agricultural sector, despite some signs of disengagement. Yet, the state elites are not the only actors that benefit from the related reforms. Large farmers that already export to the EU continue to benefit from the ENP, whereas subsistence farmers are further marginalised, due to the high cost of certification for exports, privatisations and limited access to credit.

In the industrial sector, the EU companies form a solid block, which want to expand further into the North African markets. The standardisation process further increases the comparative advantage that the European companies have against the North African producers. Even if in theory, the conclusion of ACAAs could benefit SMEs, the fact that the North African companies are undercapitalised does not leave them a lot of space for investments and access to the EU market. In addition, the support of the ENP to other regional initiatives, such as the Agadir Agreement, reflects the pressures of the European industrialists on European leaders and consequently to the EU institutions to align the regional regulations in a way that would benefit their interests.

The effects of the Agadir agreement are not only bilateral, but they have wider consequences. The agreement is based on the EU rules and the charter states that the main aim is to facilitate the creation of a Euro-Mediterranean area for free trade 'in realisation of the aims of the "Barcelona Declaration"' ("Agadir Agreement" 2004, pp. 1-2). As such, the agreement allows the EU companies to penetrate deeper into the North African markets. On the other hand, the further integration of the partner countries into the EU market works as a barrier to South-South plans, even if such initiatives are supported by the ENP APs.

Yet, in order to complete the picture of the ENP, we need to go beyond the asymmetrical gains to the social actors and reveal the mechanisms that served the reverberation of the EU pressures to North African governments. As mentioned above, the low politicisation of the ENP facilitated the discussions between the two sides and the state elites of the North African countries have managed to retain their power.

As the main negotiator of the EU for the creation of the ENP, the EC played an important role in the communication of EU preferences to the North African countries. The new programmes that the EU has created after the Arab Spring are among the main tools that the Commission has used for persuading the North African countries to accept EU priorities.

Unsurprisingly, the progress reports have captured the slow growth of the two countries after the Arab Spring. More importantly, they demonstrate continuity in the EU response to the Arab Spring uprisings. In particular, the newly created programmes reproduce the development of a dual agricultural market in Tunisia and Morocco and deprive North African SMEs, which are the spine of the North African economies. As this article has argued, the ENP has perpetuated older dichotomies and divisions within North African countries, which continue to work as satellites of 
the EU economy. Under these conditions, and as long as the configuration of power has not fundamentally changed within the countries of the EU and North Africa, it would not be a surprise to see the EU demanding further reforms, which widen the gap between the privileged groups and disadvantaged people. As with previous ones, these too will most likely result in the Tunisian and Moroccan governments implementing programmes that further undermine their sustainable economic development. 


\section{References}

Agadir Agreement. (2004). Retrieved from

http://www.agadiragreement.org/AgadierAgrement/Agreementtext.aspx

Aloui, O., \& Lahcen, K. (2004). The Cost of Compliance with SPS Standards for Moroccan Exports: A Case Study (Discussion Paper). Washington, DC: The World Bank.

Amirah-Fernández, H., \& Behr, T. (2013). The missing spring in the EU's Mediterranean policies (Policy Paper). Real Instituto Elcano.

A new national strategy for agriculture. (2008, January 12). Oxford Business Group. Retrieved from http://farmlandgrab.org/7943

Attinà, F. (2003). The Euro-Mediterranean Partnership Assessed: The Realist and Liberal Views. European Foreign Affairs Review, 8, 181-199.

Barbé, E., \& Johansson-Nogués, E. (2008). The EU as a modest "force for good": the European Neighbourhood Policy. International Affairs, 84(1), 81-96.

Bates, R. H. (1981). Markets and States in Tropical Africa: The Political Basis of Agricultural Policies. University of California Press.

Bensaad, A. (2007). The Mediterranean Divide and Its Echo in the Sahara: New Migratory Routes and New Barriers on the Path to the Mediterranean. In T. Fabre \& P. Sant Casia (Eds.), Between Europe and the Mediterranean: The Challenge and the Fears. Hampshire: Palgrave Macmillan.

Bicchi, F. (2011). The Union for the Mediterranean, or the Changing Context of EuroMediterranean Relations. Mediterranean Politics, 16(1), 3-19. doi:10.1080/13629395.2011.547365

Bilgin, P. (2009). EU Security Policies towards the Mediterranean: The Ethical Dimension-what do we know and what else should we know? INEX Policy 
Brief No. 2, December 2009 (Working Paper 6). Oslo: International Peace Research Institute. Retrieved from http://aei.pitt.edu/14991/

Borras, S. (2003). Questioning the pro-market critique of state-led agrarian reforms. The European Journal of Development Research, 15(2), 109-132. doi:10.1080/09578810312331287505

Buras, P., \& Pomorska, K. (2006). Poland and the European Neighbourhood Policy. In M. Overhaus, H. Maus, \& S. Harnisch (Eds.), The New Neighbourhood Policy of the European Union Perspectives from the European Commission, France, Germany, Poland, Ukraine and Moldova (Vol. 7). Retrieved from http://www.deutsche-aussenpolitik.de/newsletter/issue19.pdf

Cadot, O., Augier, P., Gourdon, J., \& Malouche, M. (2011). Non-tariff measures in the MNA region: Improving governance for competitiveness (Working Paper). Retrieved from http://works.bepress.com/ocadot/26

Chemingui, M. A., \& Thabet, C. (2007). Agricultural Trade Liberalization and Poverty in Tunisia: Macrosimulation in a General Equilibrium Framework (No. 67). African Trade Policy Centre. Retrieved from http://repository.uneca.org/bitstream/handle/10855/3579/Bib.\%2028631_l.pdf ?sequence $=1$

Daguzan, J. (2005). Maghreb Machrek - Marges Et Mondialisation Les Migrations Transsahariennes No. 185 Automne /Autumn 2005 (First Edition.). Choiseul. Darbouche, H. (2011). Third Time Lucky? Euro-Mediterranean Energy Co-operation under the Union for the Mediterranean. Mediterranean Politics, 16(1), 193211. doi:10.1080/13629395.2011.547412

De Wulf, L., \& Maliszewska, M. (2010). Prospects for Future Euro-Mediterranean Trade. Warsaw: Center for Social and Economic Research. 
DG Enterprise and Industry. (2008). Report on the implementation of the EuroMediterranean Charter for Enterprise. Brussels.

DG Enterprise and Industry. (2012a). International affairs EU-Mediterranean. Retrieved September 10, 2012, from http://ec.europa.eu/enterprise/policies/international/promotingneighbourhood/mediterranean/\#h2-3

DG Enterprise and Industry. (2012b). Single market for goods New Approach. Retrieved September 9, 2012, from http://ec.europa.eu/enterprise/policies/single-market-goods/regulatorypolicies-common-rules-for-products/new-approach/index_en.htm DG Enterprise and Industry. (2013). Single market for goods Agreements on Conformity Assessment and Acceptance of industrial products (ACAA). Retrieved March 3, 2013, from http://ec.europa.eu/enterprise/policies/singlemarket-goods/international-aspects/acaa-neighbouringcountries/index_en.htm

Directorate General for Economic and Financial Affairs. (2005). European Neighbourhood Policy: Economic Review of ENP Countries (No. 18). Brussels: European Commission.

Egan, M. (2002). Setting standards: Strategic advantages in international trade. Business Strategy Review, 13(1), 51-64.

ENPI. (2012). Morocco: EIB provides $€ 42.5$ million for irrigation and agriculture. Retrieved November 26, 2014, from http://www.enpiinfo.eu/medportal/news/latest/30545/Morocco:-EIB-provides\%E2\%82\%AC42.5-million-for-irrigation-and-agriculture 
ERT. (2005). ERT recommendations on priorities for EU financial assistance to the Neighbouring Countries. Brussels: European Round Table of Industrialists.

Euro-Mediterranean Business Summit sets up business confederation. (2002, March 7). Retrieved August 6, 2010, from http://www.euractiv.com/eastmediterranean/euro-mediterranean-business-summit-sets-businessconfederation/article-112584

European Commission. (2004a). EU/Morocco Action Plan. Brussels. Retrieved from http://ec.europa.eu/world/enp/pdf/action_plans/morocco_enp_ap_final_en.pdf European Commission. (2004b). EU/Tunisia Action Plan. Brussels. Retrieved from http://ec.europa.eu/world/enp/pdf/action_plans/tunisia_enp_ap_final_en.pdf European Commission. (2006). Euro-Med Association Agreements: Agricultural Trade - Regional Impacts in the EU (Proceedings of the Workshop).

Brussels: European Commission. Retrieved from ftp://ftp.jrc.es/pub/EURdoc/PB2006IPTS3548.pdf European Commission. (2008). Implementation of the European Neighbourhood Policy in 2007 (No. COM(2008)164). Brussels: European Commission. European Commission. (2009a). Development and Cooperation EuropeAid.

Retrieved November 19, 2009, from

http://ec.europa.eu/europeaid/where/neighbourhood/countrycooperation/egypt/egypt_en.htm

European Commission. (2009b). Implementation of the European Neighbourhood

Policy in 2008 Progress Report Egypt (No. SEC(2009) 523/2). Brussels: European Commission.

European Commission. (2010, March 3). EUROPE 2020 A strategy for smart, sustainable and inclusive growth. European Commission. 
European Commission. (2011a). A New Response to a Changing Neighbourhood A review of European Neighbourhood Policy (No. COM(2011) 303). Brussels: European Commission.

European Commission. (2011b). Mise en oeuvre de la politique européenne de voisinage en 2010 Rapport pays : Tunisie (No. SEC(2011) 652). Brussels: European Commission.

European Commission. (2011c, September 27). EU response to the Arab Spring: the SPRING Programme. Retrieved September 10, 2012, from http://europa.eu/rapid/press-release_MEMO-11-636_en.htm

European Commission. (2012, June 1). ENPARD Conference on Strategic Modernisation of Agriculture in EU Neighbourhood countries (31/0501/06/2012, Brussels). Retrieved March 3, 2013, from http://ec.europa.eu/agriculture/events/enpard-workshop-2012_en.htm

Eurostat. (2010). Agriculture Database. Retrieved March 21, 2011, from http://epp.eurostat.ec.europa.eu/portal/page/portal/agriculture/data/database FIPA. (2006). Agrofood industries in Tunisia. Tunis: Foreign Investment Promotion Agency (FIPA). Retrieved from http://www.investintunisia.tn/document/222.pdf

FIPA. (2014). Retrieved November 27, 2014, from http://www.investintunisia.tn/site/en/article.php?id_article=844

Ghoneim, A. F. (2007). Examining the Deep Integration Aspects of the EU-South Mediterranean Countries: Comparing the Barcelona Process and Neighbourhood Policy, the Case of Egypt (No. FEM 31-08). FEMISE.

Gillespie, R. (2011a). Adapting to French "Leadership"? Spain's Role in the Union for the Mediterranean. Mediterranean Politics, 16(1), 59-78. doi:10.1080/13629395.2011.547379 
Gillespie, R. (2011b). The Union for the Mediterranean: An Intergovernmentalist Challenge for the European Union?*. JCMS: Journal of Common Market Studies, 49(6), 1205-1225. doi:10.1111/j.1468-5965.2011.02193.x

Hanson, B. T. (1998). What Happened to Fortress Europe?: External Trade Policy Liberalization in the European Union. International Organization, 52(01), 5585. doi:10.1162/002081898550554

Heijl, N. B. (2007). Between a Rock and a Hard Place: Euro-Mediterranean Security Revisited. Mediterranean Politics, 12(1), 1-16. doi:10.1080/13629390601136780

Henson, S., \& Loader, R. (2001). Barriers to Agricultural Exports from Developing Countries: The Role of Sanitary and Phytosanitary Requirements. World Development, 29(1), 85-102.

Hettne, B. (2007). Interregionalism and World Order: The diverging EU and US Models. In M. Telò (Ed.), European Union and New Regionalism: Regional Actors and Global Governance in a Post-Hegemonic Era. Ashgate Publishing, Ltd.

Holden, P. (2009). In Search of Structural Power: EU Aid Policy as a Global Political Instrument. Ashgate Publishing, Ltd.

Holm, U. (2008). North Africa: A Security Problem for Themselves, for the EU and for the US (DIIS Report No. 2). Copenhagen: Danish Institute for International Studies. Retrieved from http://se2.isn.ch/serviceengine/Files/EINIRAS/17634/ipublicationdocument_si ngledocument/342551FB-FF8D-4FCC-8D11021EFE6C698B/en/Cooperation_Democratisations.pdf 
Jaffee, S. (1999). Southern African Agribusiness: Gaining Through Regional Collaboration. World Bank Publications.

Joffé, G. (2007). EU and the Mediterranean: Open Regionalism or Peripheral Dependence? In M. Telò (Ed.), European Union and New Regionalism: Regional Actors and Global Governance in a Post-Hegemonic Era. Ashgate Publishing, Ltd.

Johansson-Nogués, E. (2004). Profiles: A "Ring of Friends"? The Implications of the European Neighbourhood Policy for the Mediterranean. Mediterranean Politics, 9(2), 240-247. doi:10.1080/1362939042000221295

Johansson-Nogués, E. (2011). The UfM's Institutional Structure: Making Inroads towards "Co-Ownership"? Mediterranean Politics, 16(1), 21-38. doi:10.1080/13629395.2011.547369

Jouili, M. (2009). Tunisian agriculture: Are small farms doomed to disappear? (No. 52816). 111th Seminar, June 26-27, 2009, Canterbury, UK: European Association of Agricultural Economists. Retrieved from http://econpapers.repec.org/paper/agseaa111/52816.htm

Knudsen, R. A. (2013). Privatization in Kosovo: "Liberal Peace" in Practice. Journal of Intervention and Statebuilding, 7(3), 287-307. doi:10.1080/17502977.2012.734559

Kourtelis, C. (2011). The European Neighborhood Policy in North Africa: The politics of EU foreign Assistance (Working Paper No. 3/2011). Firenze: CIRES.

Kourtelis, C. (2014). Transferring Accession Programmes to the Arab Mediterranean partners: A comparative analysis between IPARD and the ENP reforms in the agricultural sector of the EU neighbouring countries. Presented at the The ENP in Comparatice Perspective, Bruges. 
López-Cálix, J. R., Walkenhorst, P., \& Diop, N. (2010). Trade Competitiveness of the Middle East and North Africa: Policies for Export Diversification. World Bank Publications.

Loxley, J. (1983). Berg Report: Accelerated Development in Sub-Saharan Africa. Review of African Political Economy, 10(27), 198-204.

Lutterbeck, D. (2006). Policing Migration in the Mediterranean. Mediterranean Politics, 11(1), 59-82. doi:10.1080/13629390500490411

Minoia, P. (2012). Mega-Irrigation and Neoliberalism in Postcolonial States: Evolution and Crisis in the Gharb Plain, Morocco. Geografiska Annaler: Series B, Human Geography, 94(3), 269-286. doi:10.1111/j.14680467.2012.00414.x

Minot, N., Chemingui, M. A., Thomas, M., Dewina, R., \& Orden, D. (2010). Trade liberalization and poverty in the Middle East and North Africa. International Food Policy Research Institute. Retrieved from http://www.ifpri.org/publication/trade-liberalization-and-poverty-middle-eastand-north-africa

Montanari, M. (2007). The Barcelona Process and the Political Economy of EuroMediterranean Trade Integration*. JCMS: Journal of Common Market Studies, 45(5), 1011-1040.

Moroccan SMEs plagued by opaque credit access. (2010, September 9). Retrieved November 19, 2012, from http://www.femise.org/en/2010/09/discussions/l\%E2\%80\%99opacite-desmodalites-d\%E2\%80\%99acces-au-credit-penalise-les-pme-marocaines/ Morocco: EIB lends $42.5 \mathrm{mln}$ for irrigation and agriculture. (2014). Retrieved November 27, 2014, from 
http://www.ansamed.info/ansamed/en/news/sections/enpi/2012/10/09/Morocc o-EIB-lends-42-5-mIn-irrigation-agricolture_7604727.html

Morocco to sell farmlands to foreign bidders. (2004, October 20). Afrol News.

Retrieved from http://www.afrol.com/articles/14598

Morsy, H., \& Zouk, N. (2013, May 25). The unfinished business of structural reforms in the Southern and Eastern Mediterranean countries. Retrieved June 6, 2013, from http://www.ebrd.com/pages/news/features/structural-reformssemed.shtml

Moyo, S. (2007). Land in the Political Economy of African Development: Alternative Strategies for Reform. Africa Development, 32(4), 1-34.

Nucifora, A. (2014). How Ben Ali Policies Continue to Impoverish Tunisians. Retrieved November 30, 2014, from http://blogs.worldbank.org/futuredevelopment/how-ben-ali-policies-continueimpoverish-tunisians

Obeidat, O. (2014, February 8). Jordan, EU urge more Arab states to join Agadir Agreement. Retrieved July 1, 2014, from http://jordantimes.com/jordan-euurge-more-arab-states-to-join-agadir-agreement

Petrey, L. A., \& Johnson, R. W. M. (1993). Agriculture in the Uruguay Round: Sanitary and Phytosanitary Measures. Review of Marketing and Agricultural Economics, 61(03). Retrieved from http://ideas.repec.org/a/ags/remaae/9626.html

Privatisation in Morocco extends to state land leases. (2005, September 15). Business Intelligence Middle East. Retrieved from http://www.bime.com/main.php?id=2058\&t=1\&c=34\&cg= 
Putnam, R. D. (1988). Diplomacy and domestic politics: the logic of two-level games. International Organization, 42(03), 427-460. doi:10.1017/S0020818300027697

Rijkers, B., Freund, C., \& Nucifora, A. (2014). All in the Family State Capture in Tunisia (Policy Research Working Paper No. 6810). World Bank.

Rijkers, B., Nucifora, A., \& Freund, C. (2014). All in the Family: State Cupure in Tunisia (Policy Research Working Paper No. 6810). World Bank.

Sykes, A. O. (1995). Product Standards for Internationally Integrated Goods Markets. Brookings Institution Press.

Talani, L. S. (2009). From Egypt to Europe: Globalisation and Migration Across the Mediterranean. London: Tauris Academic Studies.

Tunisian Ministry of Industry and Technology. (n.d.). What is an ACAA with the EU? Retrieved September 9, 2012, from http://www.industrie.gov.tn/marquagece/www/en/doc. asp?mcat=59\&mrub=150

United Nations Economic Commission for Africa. (2013). Regional integration and development of intra-regional trade in North Africa: what potential trade? Rabat: United Nations.

Wesley Scott, J. (2005). The EU and "Wider Europe": Toward an Alternative Geopolitics of Regional Cooperation? Geopolitics, 10(3), 429-454. doi:10.1080/14650040591003471

Zaiotti, R. (2007). Of Friends and Fences: Europe's Neighbourhood Policy and the "Gated Community Syndrome." Journal of European Integration, 29(2), 143162. doi:10.1080/07036330701252581 
